\title{
Effect of Warming on the Structure and Function of a Boreal Black Spruce Forest Ecosystem
}

\section{Final Report for DOE Grant DE-FG02-02ER63363}

\author{
Prepared by Dr. Stith T. Gower \\ Department of Forest and Wildlife Ecology \\ University of Wisconsin - Madison \\ Madison, WI 53706
}

There is increasing evidence that global warming is underway, and there is growing concern about its effects on the structure and function of the terrestrial biosphere (IPCC 1996, Rind 1999, Karl et al. 2000). The direct and indirect effects on ecosystem processes that determine the species composition, structure and function of terrestrial ecosystems are likely to be complex (Rustad et al. 2001). Shaver et al. (2000) suggested that on a global scale ecosystem response will be more variable to warming than elevated carbon dioxide $\left(\mathrm{CO}_{2}\right)$ for several reasons. One important factor is temperature increase will vary geographically, while increase in $\mathrm{CO}_{2}$ will be relatively uniform. Also the variable response time of soil and vegetation to temperature and the well-published exponential response of metabolic processes to temperature further complicate ecosystem response. Careful, processbased studies are needed to demonstrate the effects of warming on terrestrial ecosystems.

A strong argument can be made for the need to study the effect of warming on boreal forests more than any other terrestrial biome. First, boreal forests and woodlands cover approximately $14.5 \%$ of the land surface, making them the second largest forest biome (Gower et al. 2001). Second, climate change models suggest that boreal forests will experience the greatest warming of any forest biome, with warming being greater for continental than coastal boreal forests (IPCC 1996). Third, warming will affect permafrost and water table depth, which in turn will affect rooting depth, nitrogen dynamics (Flanagan and Van Cleve 1983), although these complex interrelationships are poorly understood for poorly drained boreal soils (citation here). Fourth, the soil carbon density is greater in boreal forest and peatland soils than the soil than other forest biomes (Schlesinger 1997). The large amount of carbon stored in the cold or frozen soils makes boreal forests extremely sensitive to climate change (Gorham 1991). Goulden et al. (1998) concluded that the warmer than normal summer temperatures in northern Manitoba were responsible for a mature black spruce (Picea mariana) ecosystem switching from a carbon sink to a carbon source. The large size of the boreal forest, the large amount of carbon contained in the soil, the strong effects of warming on the nitrogen and water cycles, the sensitivity of NPP and NEE to small 
climatic variation, and anticipated climate warming make the boreal forest biome a key biome to understand the effects of climate change on ecosystem structure and function.

The overall objective of this study is to examine the effects of soil and soil + vegetation warming on the structure and function of a boreal black spruce forest in northern Manitoba. The experimental design will consist of replicated soil warming plots $(12 \times 12$ $\mathrm{m})$ with a warmed open-top chamber in the center of the soil warming plot. The processbased study will increase our understanding of the effects of warming on the water, nitrogen, and carbon cycles, and their interaction, on the composition and structure of boreal black spruce forests - the dominant boreal forest ecosystem in North America. The proposed study parallels a soil warming study in northern Sweden (Linder et al. 2001), but differs in two important ways. First, the proposed study will warm both the soil and vegetation. Second, the proposed study will capture the early response of the boreal forest to warming.

\section{Methods}

\section{Site Description and Experimental Design}

The Boreal Soil and Air Warming Experiment research site is located $20 \mathrm{~km}$

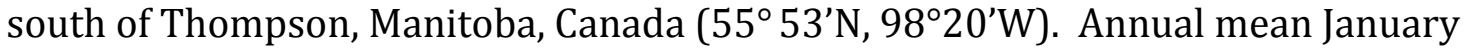
and July temperatures are -23.7 and $+17.5^{\circ} \mathrm{C}$, respectively. Mean annual precipitation is approximately $510 \mathrm{~mm}$. The study is located in a 4 hectare black spruce (Picea mariana (Mill.) BSP) plantation established by Manitoba Conservation. The soil at the site is well-drained with a $6 \mathrm{~cm}$ thick 0 horizon over montmorillonite clay. Black spruce trees were grown in greenhouses, transplanted and planted at $2 \times 2$ meter spacing. Prior to the establishment of the warming experiment, competitor woody species were removed annually to normalize competitive growth constraints, but all vegetation was allowed to establish and grow after the experiment was started.

The experimental design is a randomized complete block design comprised of four replicate blocks, with each block containing a heated and control plot $(15 \mathrm{~m} \mathrm{x}$ $15 \mathrm{~m}$ ) (Figure 1). Each plot contained approximately 64 trees. A minimum of a 2 meter buffer was maintained among all adjacent plots. The perimeter of each heated plot was trenched to $75 \mathrm{~cm}$, lined with two layers of polyethylene and backfilled to prevent roots from entering or leaving the plot.

The soil was heated using heating cable installed inside polyethylene tubing every $30 \mathrm{~cm}$ throughout the plot. The tubing was installed using a modified diamond drill which bored horizontally across the plot under the rhizosphere at approximately $20 \mathrm{~cm}$ depth. Soil heating was initiated when the soil temperature in the control plots reached $0{ }^{\circ} \mathrm{C}$. Soil temperature was held at $5^{\circ} \mathrm{C}$ above control soil temperature throughout the season except during the first and last five weeks of manipulation in which temperature was raised and lowered $1^{\circ} \mathrm{C}$ a week, respectively, to avoid thermal shock. Nested on each heated treatment is a greenhouse chamber, which controls air temperature $5^{\circ} \mathrm{C}$ above ambient air temperature and contains approximately 9 black spruce trees. This experimental design allows for the testing of soil temperature manipulation alone, (heated outside, HO) and soil \& air temperature warming (heated inside, HI). Control 


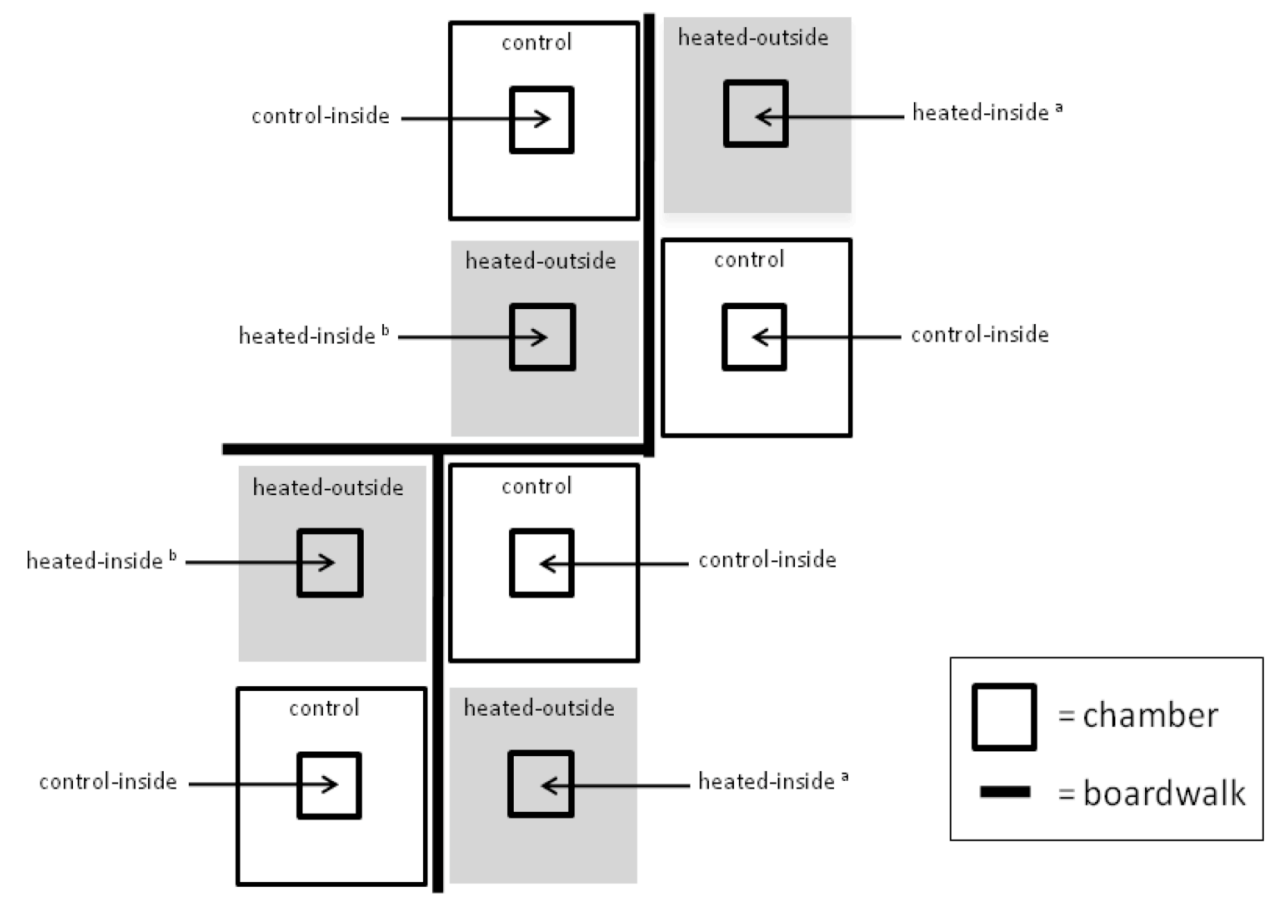

Figure 1. Schematic diagram of experimental design of study.

treatments have an open top chamber at ambient temperature, allowing chamber effect to be quantified. Control treatments outside the chamber are (control outside, $\mathrm{CO}$ ) and treatments inside the chamber are (control inside, CI). For further information on the experimental set up and performance see Gower et al. (2007).

\section{Environmental Monitoring}

Soil temperature was measured simultaneously with each $\mathrm{R}_{\mathrm{S}}$ measurement at $2 \mathrm{~cm}$ and $10 \mathrm{~cm}$ depths using digital long stem thermometers (model no. 15-078 $\mathrm{k}$, Fisher Scientific). Soil moisture was measured using two $\mathrm{ECH}_{2} \mathrm{O}-10$ probes (Decagon Inc.) and one ML2 Theta probe (Delta-T Devices Ltd.) for inside treatments, outside treatments had six $\mathrm{ECH}_{2} \mathrm{O}-10$ probes and one ML2 Theta probe. All environmental data were recorded using Campbell Scientific CR 23X dataloggers (Campbell Scientific, Logan, Utah) and type-T thermocouples.

\section{Meteorological Data}


Air temperature was held $5{ }^{\circ} \mathrm{C} \pm 1^{\circ} \mathrm{C}$ above control air temperature 96,83 , and $50 \%$ of the time for, 2005, 2006, and 2007, respectively (Figure 2). Soil temperature on the heated treatments was maintained $5{ }^{\circ} \mathrm{C} \pm 1{ }^{\circ} \mathrm{C}$ above control soil temperature for 100,97 , and $94 \%$ of the time for 2005,2006 and 2007 , respectively (Figure 2). Aging heaters and the addition of a new section of chamber to accommodate tree growth reduced the ability of heated chambers to hold air temperature at the target temperature in 2007 . However, we were able to maintain $5{ }^{\circ} \mathrm{C} \pm 1.5^{\circ} \mathrm{C}$ for $77 \%$ of the time in 2007 . Sapwood temperature was highly influenced by air temperature and reflected a similar difference of $5^{\circ} \mathrm{C} \pm 1{ }^{\circ} \mathrm{C}$ for heated-inside compared to control 87, 85, and 78\% of the time for 2005,2006 , and 2007, respectively (Figure 4). Soil moisture was maintained within $5 \%$ among treatments and was not statistically different (Bronson et al. 2008). VPD was controlled in two of the four heated-inside replicates, within $0.2 \mathrm{kPa}$ of outside ambient air vapor pressure. The manipulated VPD in the two heated-inside replicates was maintained within the $0.2 \mathrm{kPa}$ threshold 91,98 and $99 \%$ of the time for 2005, 2006, and 2007, respectively. We expected to measure differences in gas exchange rates between heated-inside treatment with the VPD controlled versus the heated-inside treatment without VPD manipulation. Our hypothesis was that the heated-inside treatment with VPD controlled, which generally had lower VPD during the midday, would allow for greater stomatal conductance in the afternoon when stomates traditionally begin to close. When rates of $A_{\text {net }}, R_{\text {fol }}$, or $R_{\text {stem }}$ were analyzed between the heated-inside treatment with VPD controlled versus the heated-inside treatment without VPD manipulation, treatments were not significantly different $(P>0.1)$. It has been shown in other conifers experiments that VPD must reach a certain threshold before stomatal conductance is affected (Day, 2000). It is reasonable to believe that the VPD in our heated-inside treatment without VPD manipulation wasn't high enough to significantly reduce stomatal conductance, and therefore no VPD treatment differences were measured. Since there were no significant differences between the heated-inside treatment with VPD controlled and the heated-inside treatment without VPD manipulation, we grouped all four heated-inside replicates together as one treatment, heated-inside.

$A_{\text {net }}$ 


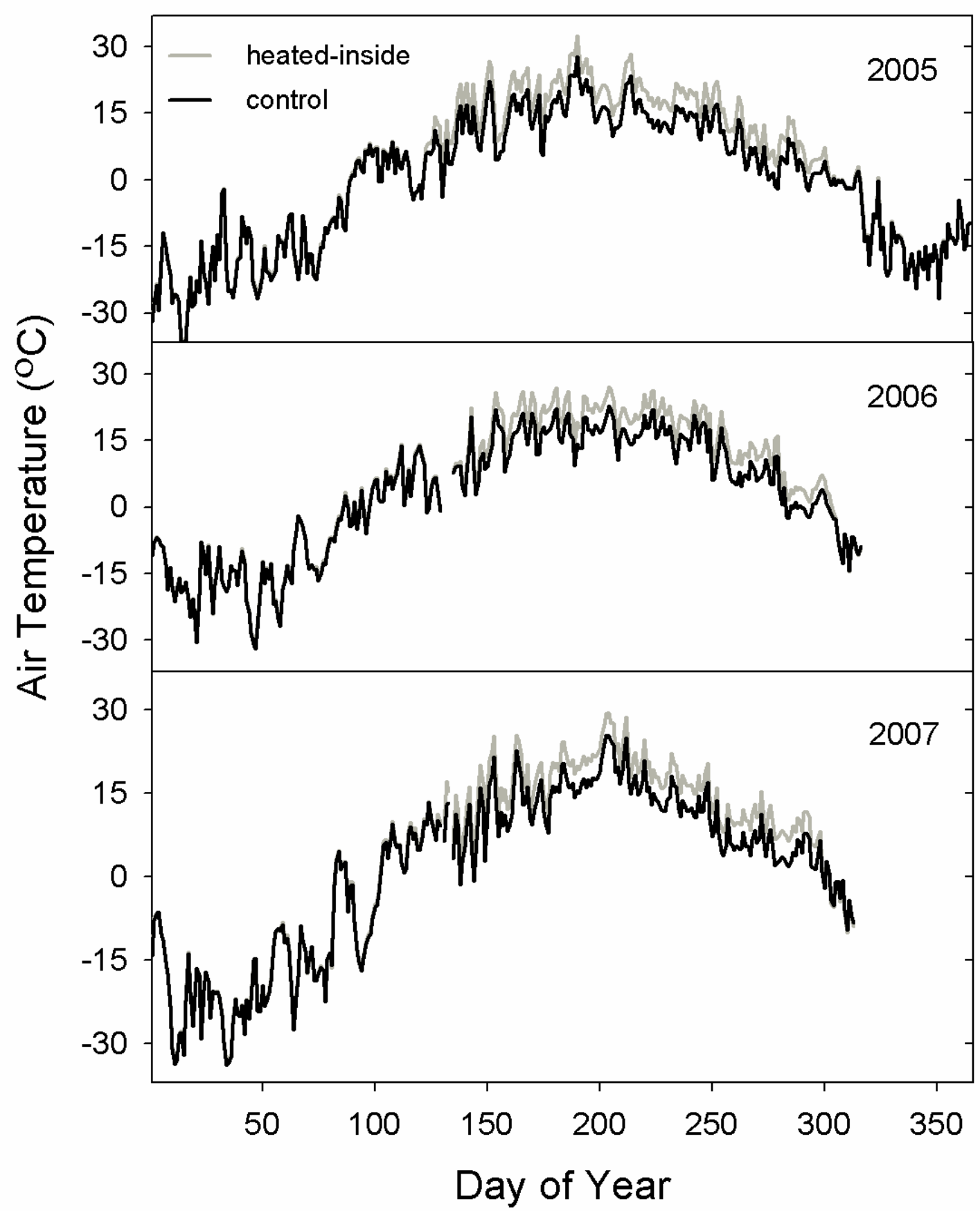

Figure 2. Air temperature inside control and heated chambers for years 2005-2007. 

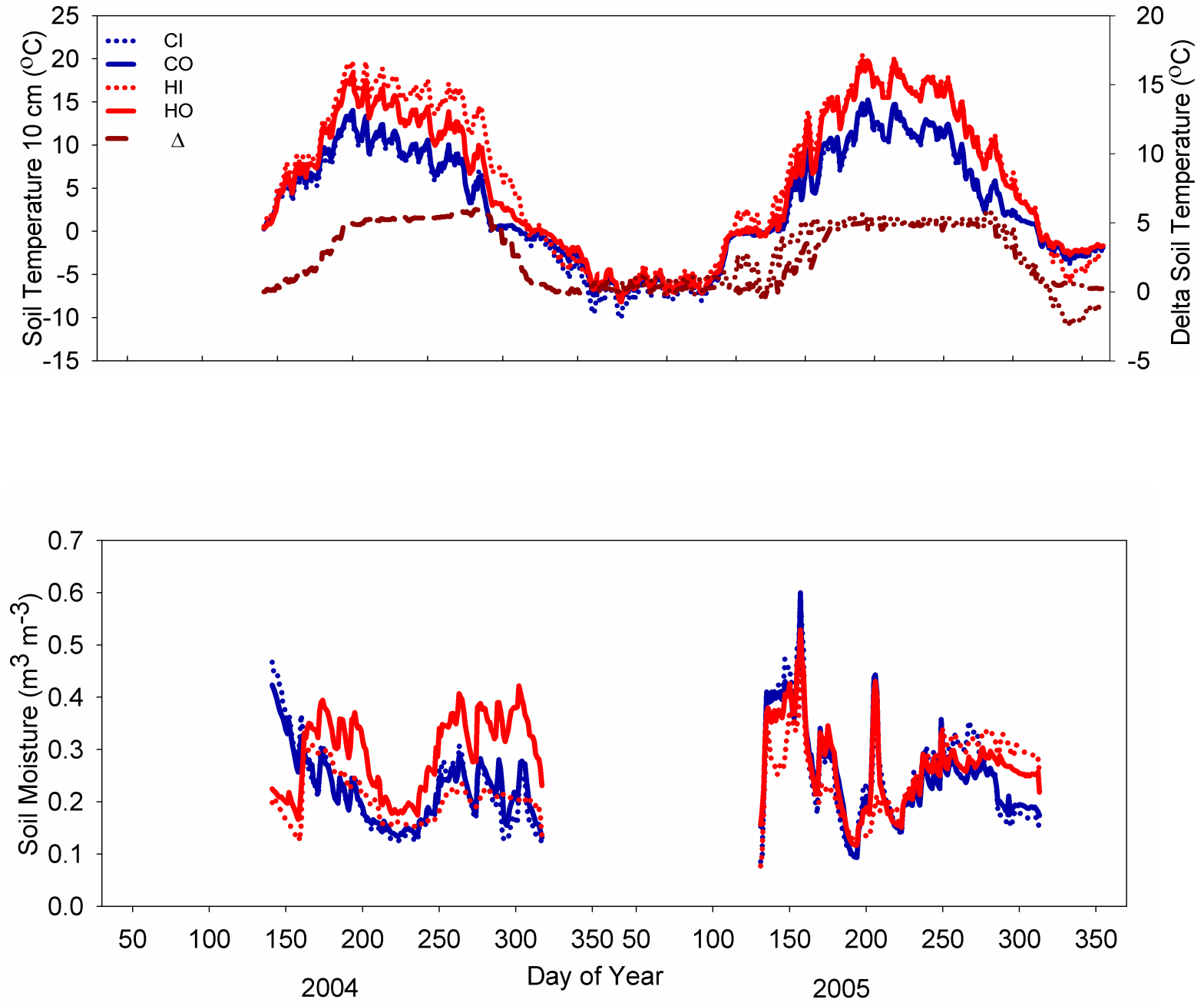

Figure 3. top panel.Average soil temperature for the four treatments: control inside chamber $(\mathrm{CI})$, control outside chamber $(\mathrm{CO})$, heated inside chamber $(\mathrm{HI})$ and heatedoutside chamber (HO). Bottom panel. Soil moisture (\% by volume for the four treatments. 


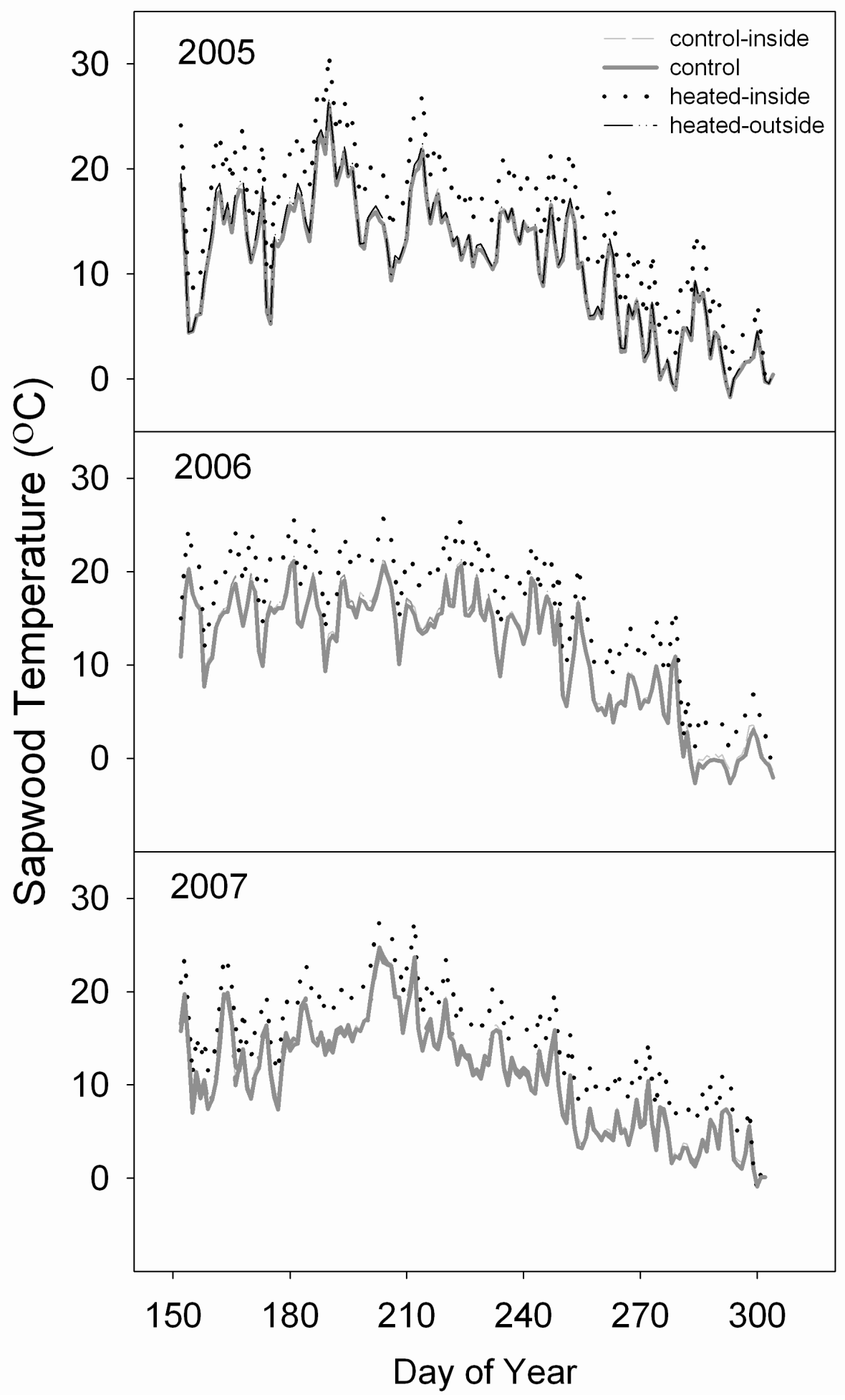

Figure 4. Sapwood temperatures of black spruce trees inside heated and control chambers. 


\section{Examine the effect of warming on phenology of overstory, understory and}

bryophyte strata. Bronson, DR, ST Gower, MT Tanner, and IG Van Herk. 2009. Effect of ecosystem warming on boreal black spruce bud burst and shoot growth. Global Change Biology 1-10.

Bud burst was measured during the first and second years of the experiment, starting in 2004, and annual shoot growth was measured for the first three years (2004-2006) of the study. On average, shoot bud burst occurred 11 and 9 days earlier in 2004 and 2005, respectively, for HI than for other treatments. However, mean cumulative degree-days required for bud burst for HI was within the standard deviation of $\mathrm{CO}$ for both years (Figure 5).

In year one of the treatments, shoot bud burst occurred earlier for $\mathrm{HI}$ than other treatments (CI, CO, HO), but final shoot length of $\mathrm{HI}$ trees was less than in $\mathrm{CO}$ trees. In the second year of warming, final shoot length was not different for HI than CO. By the third year of warming final shoot length was significantly greater for $\mathrm{HI}$ than all other treatments.

Empirical results from this study suggest that soil and air warming causes an earlier bud burst for all years of observation and greater shoot lengths by the third season of warming. Slaney et al. (2007) used single-tree chambers at the Flakaliden, Sweden research site to increase temperature and $\mathrm{CO}_{2}$ concentration on Norway spruce and showed that warming produced an earlier day of bud burst, but did not increase overall shoot length. It is unclear why the results between this experiment and Slaney et al. (2007), both with similar years of warming, observed different responses of final shoot length to warming. One possible explanation may have to do with the smaller soil surface area warmed by the single-tree chambers in Sweden compared to the larger soil surface area warmed by chambers used in this experiment. A longer growing season and greater annual shoot growth should increase carbon uptake by boreal black spruce trees in a warmer climate. 


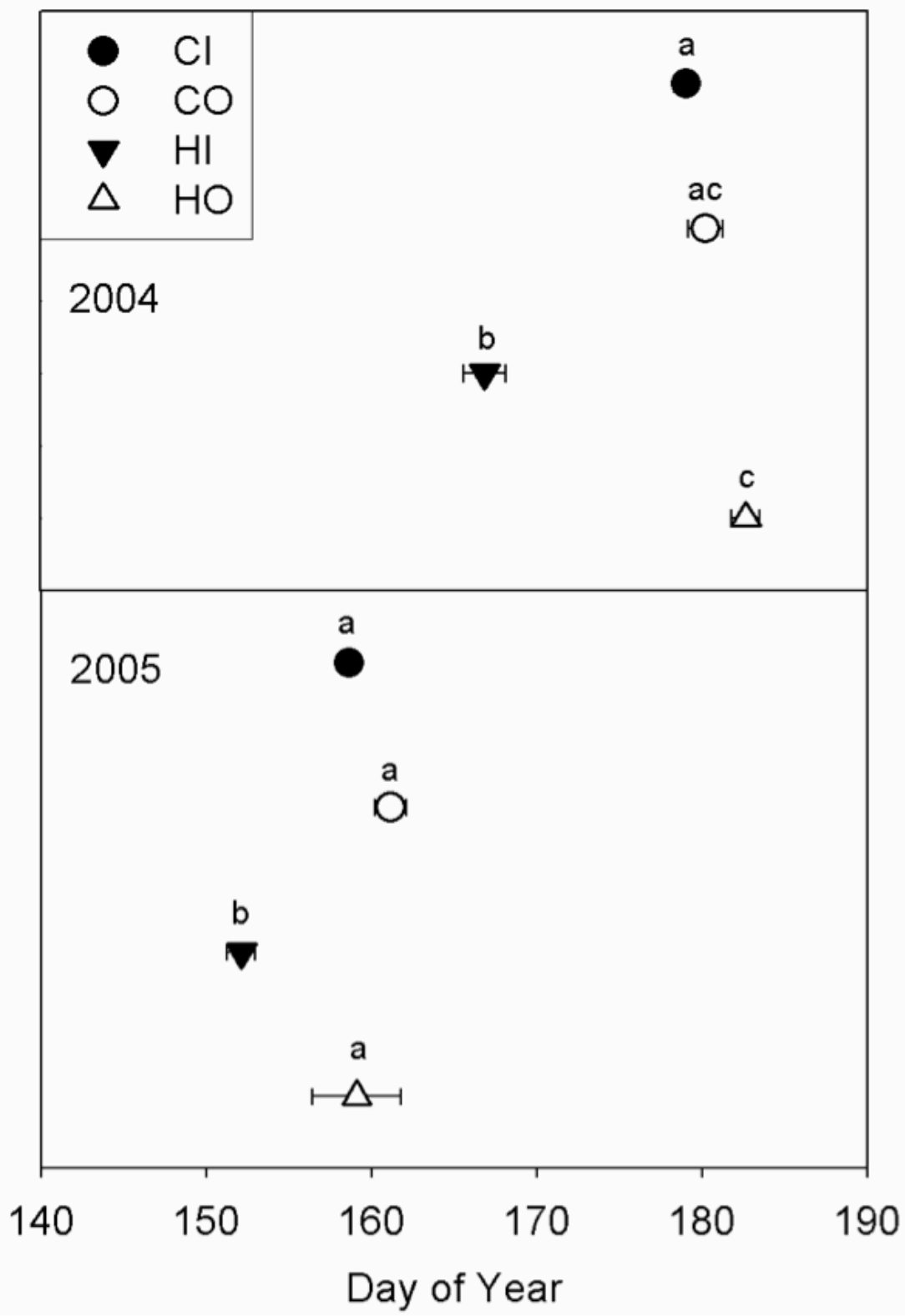

Figure 5. Figure 5. Bud burst for years 2004 and 2005, for treatments CI, CO, HI and $\mathrm{HO}$, corresponding with a) day of year and b) cumulative degree-days using $0{ }^{\circ} \mathrm{C}$ as a base temperature $\left(\mathrm{CDD}_{0}\right)$. Horizontal bars indicate \pm 1 standard deviation. Letters indicate statistically significant differences $(P \leq 0.05)$. Bud burst data was not captured in 2006. 


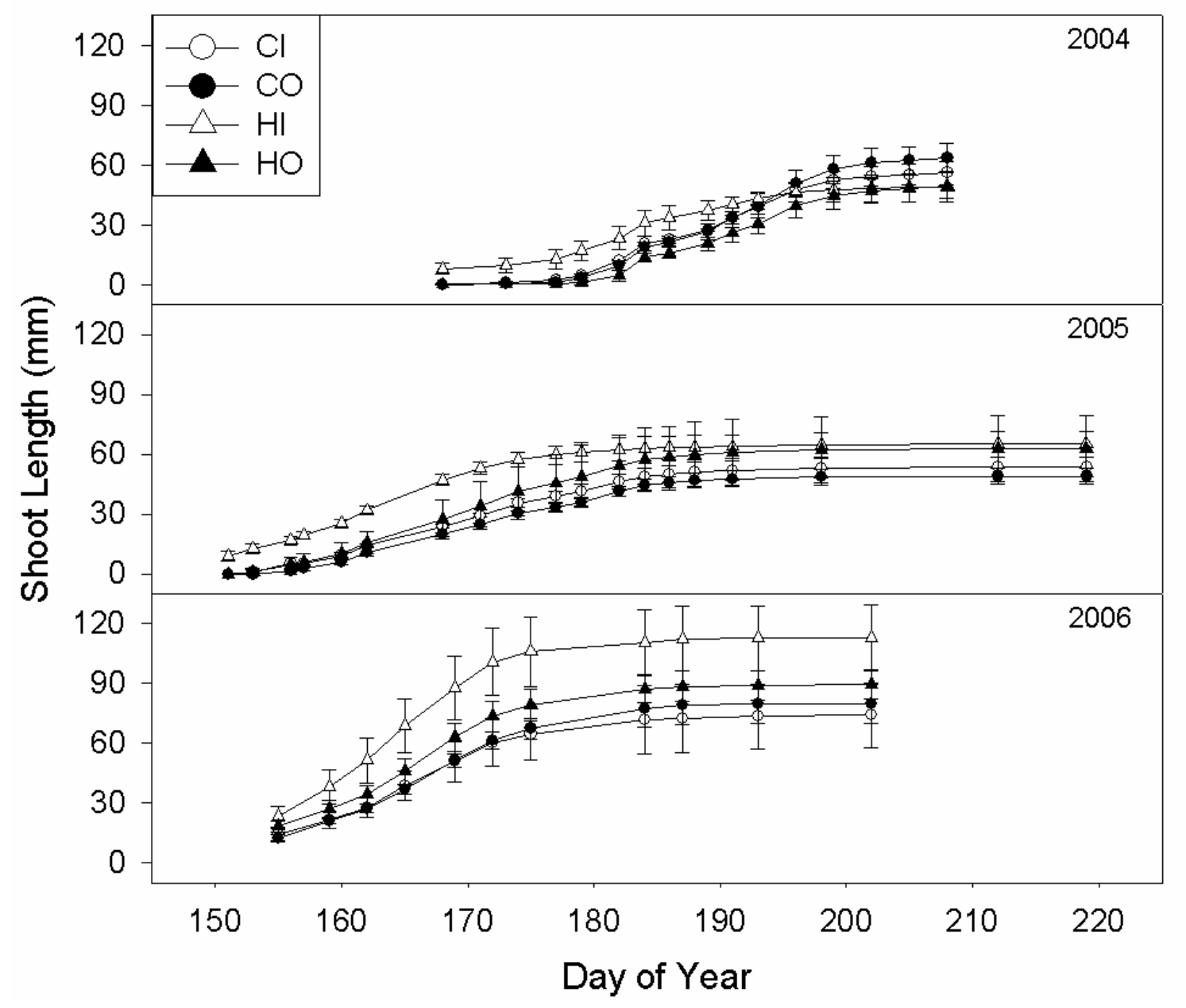

Figure 6. Relationship between shoot length and day of year. Values are based on the mean of five trees in each of four replicate blocks per treatment. 
Examine the effects of warming on major components of the carbon budget: Soil Surface CO2 flux.

The models that correlated $\mathrm{R}_{\mathrm{S}}$ to $\mathrm{T} 10$ explained more of the observed variation $(\mathrm{P}<0.001)$ than soil temperature at $2 \mathrm{~cm}(\mathrm{P}=0.795)$, therefore we used $\mathrm{T} 10$ for all further analyses. Soil surface $\mathrm{CO}_{2}$ flux $\left(\mathrm{R}_{S}\right)$ was positively correlated to $\mathrm{T} 10$ throughout both years of measurement for all four treatments (Table 1). The seasonal pattern of $R_{S}$ followed a bell shaped curve with $R_{S}$ varying the most at the warmest soil temperature (Figure 2).

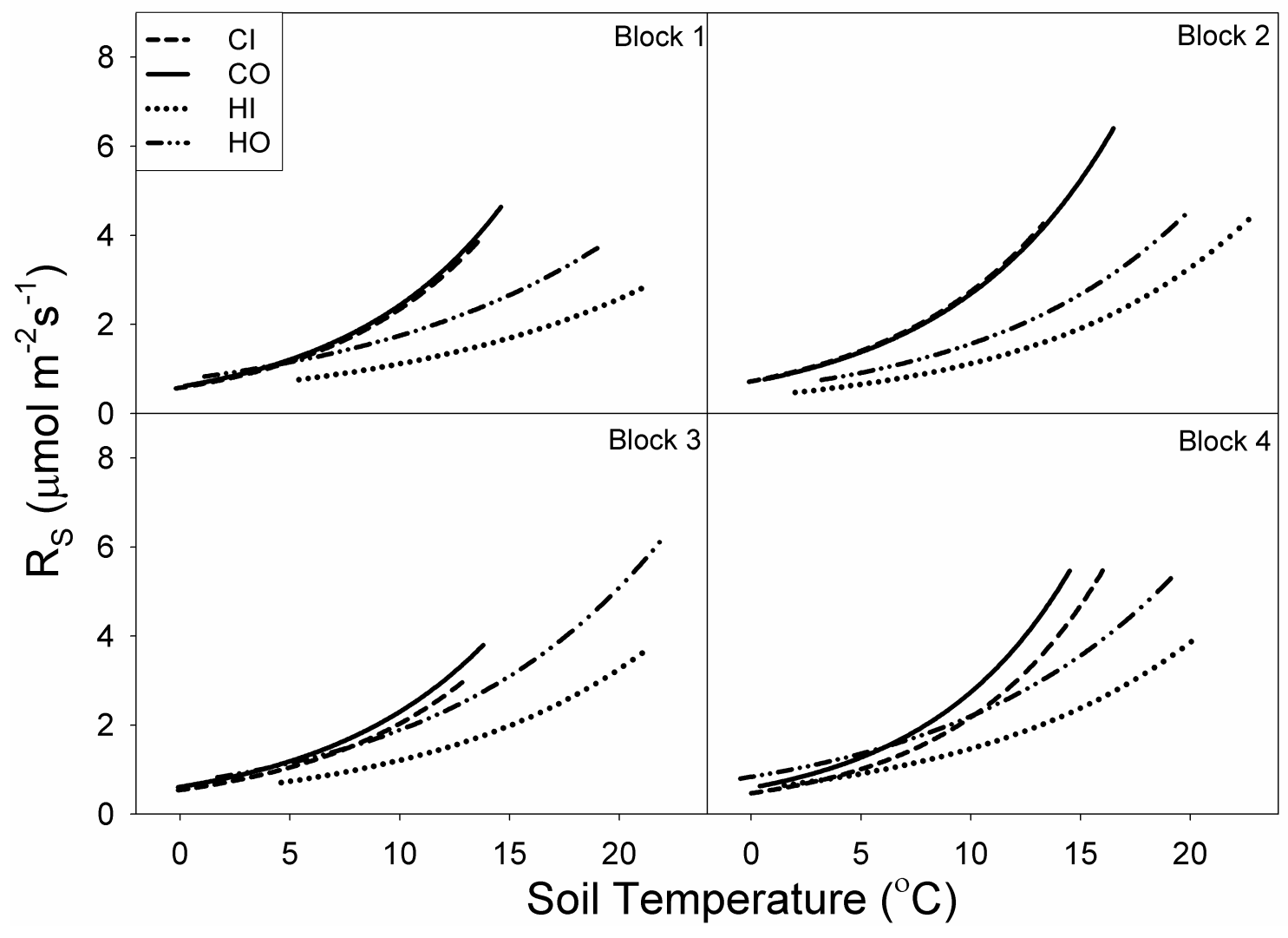

Figure 7. Model comparison among treatments for all four replicate blocks. 
The mean growing season Rs, defined as May $1^{\text {st }}$ through October 31st, for the CO treatment in 2004 was $1.49 \mu \mathrm{mol} \mathrm{m}^{-2} \mathrm{~s}^{-1}$ and $3.13 \mu \mathrm{mol} \mathrm{m}^{-2} \mathrm{~s}^{-1}$ in 2005. Soil surface $\mathrm{CO}_{2}$ flux (Rs) was positively correlated $(\mathrm{P}<0.0001)$ to soil temperature at $10 \mathrm{~cm}$ depth. The 2005 annual soil surface $\mathrm{CO}_{2}$ flux (Rs) was $465 \pm 58,424 \pm 36,420 \pm 40$ and $593 \pm 76 \mathrm{~g} \mathrm{C} \mathrm{m}^{-2} \mathrm{yr}^{-1}$ for treatments $\mathrm{CI}, \mathrm{CO}, \mathrm{HI}$ and $\mathrm{HO}$ respectively. In conclusion, whole-ecosystem warming, soil and air, in a boreal coniferous forest will not produce $\mathrm{R}_{\mathrm{S}}$ values consistent with a traditional $\mathrm{Q}_{10}$. This is one more study questioning the strength of the positive feedback between global warming and increased soil surface $\mathrm{CO}_{2}$ flux.

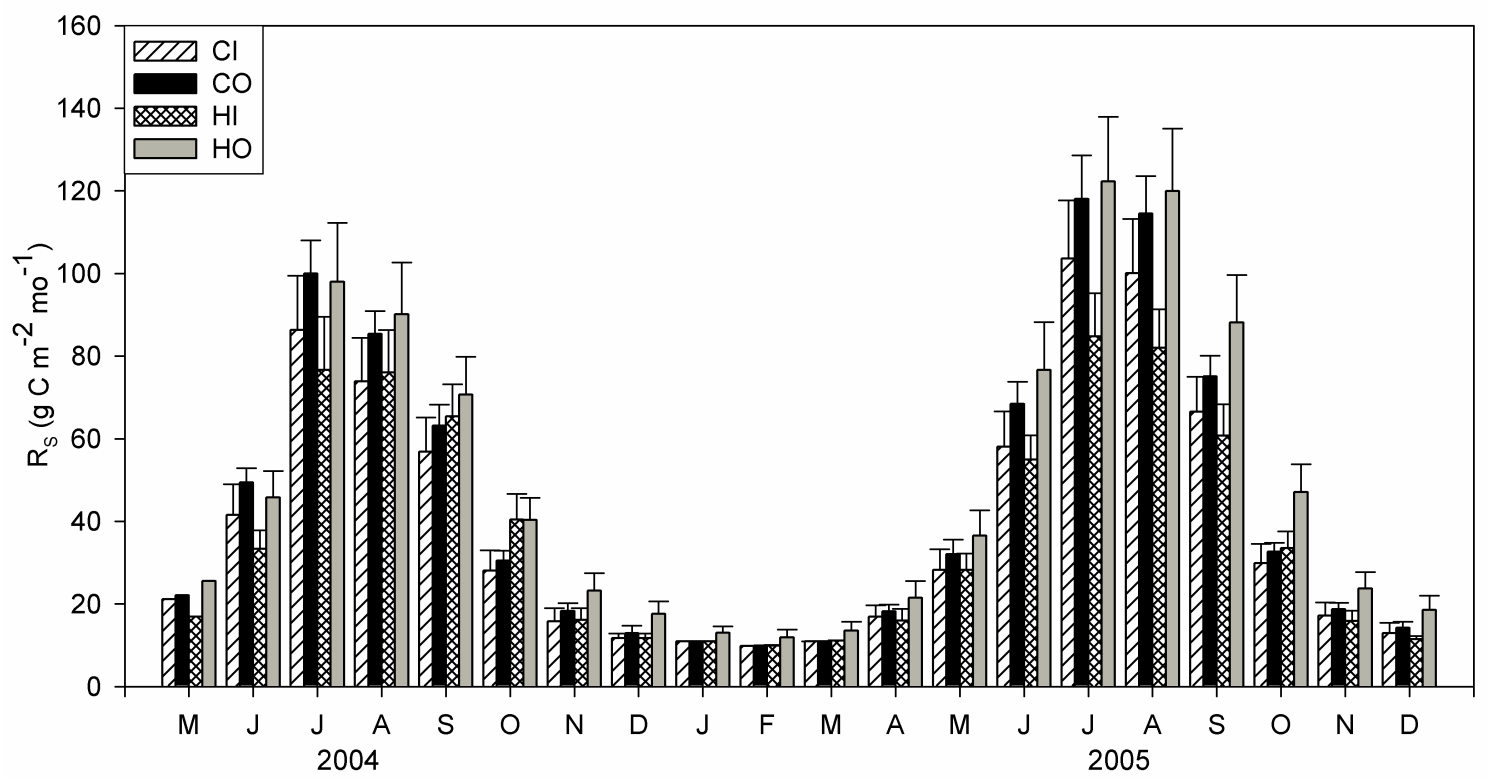

Figure 6. Modeled monthly soil surface $\mathrm{CO}_{2}$ flux $\left(\mathrm{R}_{\mathrm{S}}\right)\left(\mathrm{g} \mathrm{C} \mathrm{m}^{-2} \mathrm{mo}^{-1}\right)$ for each treatment. Means and standard error bars were calculated from the average of the four replicate blocks. 
Live fine root biomass ranged from $366 \mathrm{~g} \mathrm{~m}^{-2}$ to $490 \mathrm{~g} \mathrm{~m}^{-2}$ in 2004 and $177 \mathrm{~g}$ $\mathrm{m}^{-2}$ to $328 \mathrm{~g} \mathrm{~m}^{-2}$ in 2005 (Figure 9). Live fine root biomass was significantly greater $(\mathrm{P}<0.0001)$ in 2004 than 2005 for all treatments. Live fine root biomass did not differ significantly between control and heated treatments for 2004, but was significantly less $(\mathrm{P}<.01)$ for the heated than control plots in 2005 .

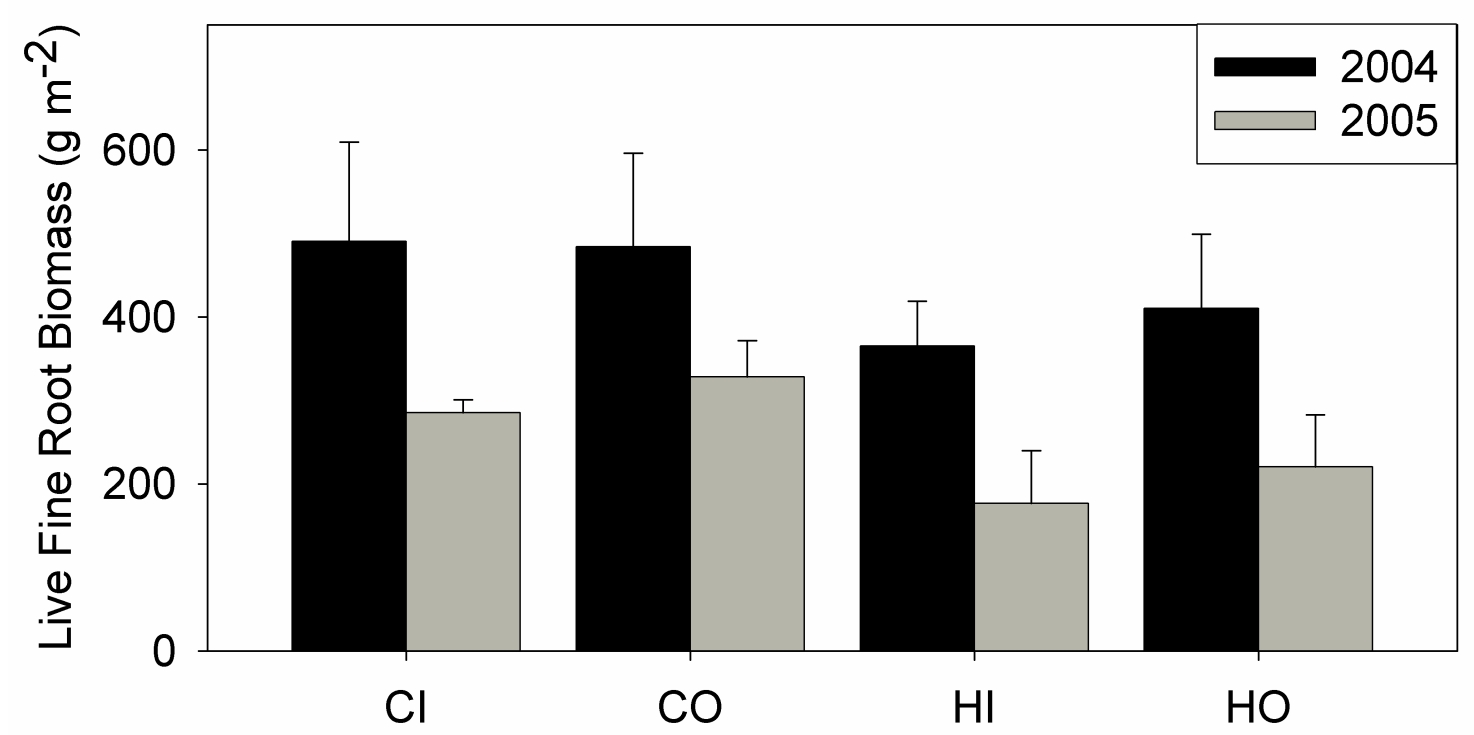

Figure 9. Live fine root biomass for each treatment for years 2004 and 2005. Error bars are produced by averaging the four replicate blocks per treatment.

The results of this study corroborate the results reported by other scientists that warming did not increase $\mathrm{R}_{\mathrm{S}}$ in forest ecosystems (Strömgren, 2001). Unlike all other studies, we irrigated the soil to avoid the potential adverse effect of soil moisture on root and microbial activity (Stark and Firestone, 1995). The physiological basis for the observed response remains poorly understood, but can be attributed to two possible general explanations: i) physiological acclimation and ii) reduction of substrate. Physiological acclimation can occur by the soil microbes, the roots and mycorrhizae, or both. Previous studies have shown that warming does not increase microbial respiration if other factors inhibit microbial activity (MacDonald et al., 1995; Zak et al., 1999). Both Luo et al. (2001) and Strömgren (2001) have speculated that microbial acclimation may explain the lack of increased $\mathrm{R}_{\mathrm{S}}$ in response to warmer soil temperatures, and this hypothesis is supported by empirical data ( $\mathrm{Zogg}$ et al., 1997). Roots contribute 46 to 50 percent of the total $\mathrm{CO}_{2}$ flux from the soil (Hanson et al. 2000, Bond-Lamberty et al. 2004b) and therefore 
represent a second possible source of acclimation. In this study, live fine root biomass was less in the heated than control plots by $24 \%$ and $46 \%$ in 2004 and 2005 respectively, with the reduction being statistically significant in 2005. Atkins et al. (2001) highlight the possibility that potentially rapid changes in adenylate control might underlie root acclimation response to temperature and has the potential to influence the total amount of $\mathrm{CO}_{2}$ respired by roots daily. A physiological model based on their hypothesized acclimation mechanisms illustrated that rapid acclimation can result in near-perfect homeostasis of respiration rates and minimize annual root respiration. Preliminary results from this study show that more emphasis should be placed on studying fine root biomass and its response to increases in soil temperature. Several studies have showed increases in available nitrogen with warming or incubation (Lükewille and Wright, 1997; Rustad et al., 2001). More readily available nitrogen may account for a reduction in root biomass, thereby decreasing the contribution to the overall $R_{S}$. However, explanations for these types of phenomena are rarely single-ended and usually invoke multifaceted mechanisms.

Examine the effects of warming on major components of the carbon budget: Net photosynthesis and stem respiration. Bronson, DR and ST Gower. 2009. Ecosystem warming does not affect photosynthesis or aboveground autotrophic respiration for boreal black spruce. Tree Physiology (in press).

Gas exchange rates ranged between $0.71-4.66,0.04-0.74$, and $0.1-1.0 \mathrm{umol} \mathrm{m}^{-2}$ $\mathrm{s}^{-1}$, for $A_{n e t}, R_{f o l}$ and $R_{\text {stem }}$, respectively. Treatment differences for $A_{n e t}, R_{f o l}$, and $R_{\text {stem }}$ were not significant in any of the three years of measurements.

Table 1. Net assimilation $\left(\mu \mathrm{mol} \mathrm{m}{ }^{-2} \mathrm{~s}^{-1}\right)$ for treatments: control-inside (chamber maintained at outside ambient air temperature), control, heated-inside $\left(+5^{\circ} \mathrm{C}\right.$ soil and air temperature) and heated-outside $\left(+5^{\circ} \mathrm{C}\right.$ soil-only warming). Measured year, foliage age (years), number of replicates $(n)$, and $P$-values are given. 


\begin{tabular}{|c|c|c|c|c|c|c|c|}
\hline \multirow[b]{2}{*}{ Measured Year } & \multirow[b]{2}{*}{ Foliage Age } & \multicolumn{5}{|c|}{ Treatments } & \multirow[b]{2}{*}{$P$-value } \\
\hline & & $n$ & $\begin{array}{l}\text { control- } \\
\text { inside }\end{array}$ & control & $\begin{array}{l}\text { heated- } \\
\text { inside }\end{array}$ & heated-outsid & \\
\hline & & & \multicolumn{4}{|c|}{ Net assimilation $\left(\mu \mathrm{mol} \mathrm{m}{ }^{-2} \mathrm{~s}^{-1}\right)$} & \\
\hline 2005 & 2 & 4 & $1.5(0.4)$ & $1.9(0.4)$ & $1.7(0.4)$ & $1.7(0.4)$ & 0.36 \\
\hline 2005 & 1 & 4 & $2.0(0.4)$ & $2.2(0.6)$ & $2.5(0.6)$ & $2.3(0.5)$ & 0.22 \\
\hline 2005 & $0^{\mathrm{a}}$ & 4 & $2.5(0.6)$ & $2.9(0.6)$ & $3.0(0.4)$ & $2.8(0.5)$ & 0.44 \\
\hline 2006 & 2 & 4 & $2.0(0.7)$ & $2.0(0.8)$ & $2.1(0.5)$ & $1.6(0.4)$ & 0.60 \\
\hline 2006 & 1 & 4 & $2.6(0.6)$ & $2.7(0.7)$ & $2.5(0.7)$ & $2.4(0.5)$ & 0.78 \\
\hline 2006 & $0^{\mathrm{a}}$ & 4 & $2.7(0.7)$ & $2.6(0.6)$ & $2.4(0.5)$ & $2.5(0.5)$ & 0.65 \\
\hline 2007 & 2 & 4 & $2.3(0.9)$ & $2.2(0.6)$ & $2.4(0.4)$ & $2.1(0.6)$ & 0.53 \\
\hline 2007 & 1 & 4 & $2.6(0.7)$ & $2.4(0.7)$ & $2.5(0.7)$ & $2.9(0.6)$ & 0.49 \\
\hline 2007 & $0^{\mathrm{a}}$ & - & & & - & & \\
\hline
\end{tabular}

a Foliage age 0 is foliage that emerged during the year.

Net assimilation values are mean values for each treatment from June through September.

Standard deviations are in parentheses. 
Table 2. Foliage respiration $\left(\mu \mathrm{mol} \mathrm{m}^{-2} \mathrm{~s}^{-1}\right)$ for treatments: control-inside (chamber maintained at outside ambient air temperature), control, heated-inside $\left(+5^{\circ} \mathrm{C}\right.$ soil and air temperature) and heated-outside $\left(+5^{\circ} \mathrm{C}\right.$ soil-only warming). Measured year, foliage age (years), number of replicates $(n)$, and $P$-values are given.

Foliage Respiration

\begin{tabular}{|c|c|c|c|c|c|c|c|}
\hline \multirow[b]{2}{*}{$\begin{array}{c}\text { Measured } \\
\text { Year }\end{array}$} & \multirow[b]{2}{*}{ Foliage Age } & \multicolumn{6}{|c|}{ Treatments } \\
\hline & & $n$ & control-inside & control & $\begin{array}{c}\text { heated- } \\
\text { inside }\end{array}$ & $\begin{array}{l}\text { heated- } \\
\text { outside }\end{array}$ & $\begin{array}{r}P- \\
\text { valı }\end{array}$ \\
\hline 2005 & 3 & 4 & $0.19(0.11)$ & $0.19(0.08)$ & $0.21(0.3)$ & $0.23(0.11)$ & 0.9 \\
\hline 2005 & 1 & 4 & $0.21(0.21)$ & $0.24(0.23)$ & $0.24(0.25)$ & $0.31(0.32)$ & 0.5 \\
\hline 2005 & $0^{\mathrm{a}}$ & 4 & $0.31(0.12)$ & $0.3(0.12)$ & $0.24(0.07)$ & $0.29(0.07)$ & 0.5 \\
\hline 2006 & 3 & 4 & $0.25(0.10)$ & $0.31(0.14)$ & $0.28(0.08)$ & $0.33(0.08)$ & 0.3 \\
\hline 2006 & 1 & 4 & $0.59(0.33)$ & $0.82(0.22)$ & $0.5(0.2)$ & $0.58(11)$ & 0.4 \\
\hline 2006 & $0^{\mathrm{a}}$ & 4 & $0.32(0.07)$ & $0.34(0.05)$ & $0.35(0.12)$ & $0.39(0.1)$ & 0.5 \\
\hline 2007 & 3 & 4 & $0.32(0.45)$ & $0.34(0.22)$ & $0.36(0.28)$ & $0.48(0.33)$ & 0.5 \\
\hline 2007 & 1 & 4 & $0.35(0.18)$ & $0.23(0.15)$ & $0.26(0.14)$ & $0.39(0.24)$ & 0.3 \\
\hline 2007 & $0^{a}$ & 4 & $0.24(0.14)$ & $0.20(0.11)$ & $0.18(0.10)$ & 0.22 (0.07) & 0.3 \\
\hline
\end{tabular}

a Foliage age 0 is foliage that emerged during the year.

Foliage respiration values are mean values for each treatment from June through September.

Standard deviations are in parentheses.

Table 3. Stem respiration $\left(\mu \mathrm{mol} \mathrm{m}{ }^{-2} \mathrm{~s}^{-1}\right)$ for treatments: control-inside (chamber maintained at outside ambient air temperature), control, heated-inside $\left(+5^{\circ} \mathrm{C}\right.$ soil and air temperature) and heated-outside $\left(+5^{\circ} \mathrm{C}\right.$ soil-only warming). Measured year, number of replicates $(n)$, and $P$-values are given.

Stem Respiration

\begin{tabular}{ccccccc} 
Measured Year & $n$ & $\begin{array}{c}\text { control- } \\
\text { inside }\end{array}$ & control & $\begin{array}{c}\text { Treatments } \\
\text { inside }\end{array}$ & $\begin{array}{c}\text { heated- } \\
\text { outside }\end{array}$ & $\begin{array}{c}P \text { - } \\
\text { value }\end{array}$ \\
\hline 2005 & 4 & $0.22(0.10)$ & $0.29(0.16)$ & $0.24(0.11)$ & $0.24(0.13)$ & 0.61 \\
2006 & 4 & $0.41(0.21)$ & $0.35(0.17)$ & $0.41(0.17)$ & $0.49(0.24)$ & 0.60 \\
2007 & 4 & $0.16(0.16)$ & $0.29(0.28)$ & $0.37(0.38)$ & $0.41(0.41)$ & 0.17
\end{tabular}

Stem respiration values are mean values for each treatment from June through

September.

Standard deviations are in parentheses. 
The results of this experiment suggest that in a warmer climate, black spruce may not have significant changes in the rate of photosynthesis or respiration. No significant treatment effects were detected when each week of $A_{\text {net }}$ measurements were analyzed for all three years of measurements $(P>0.1)$. Bergh and Linder (1999) reported that the majority of their measured $A_{n e t}$ was not significantly different between Norway spruce trees in control and soil-only warmed plots. Hall et al. (2009) reported that an increase in air temperature caused an earlier bud burst for Norway spruce and thereby an earlier positive net assimilation rate compared to control trees, but once control trees reached the net assimilation compensation point, there were no differences in net assimilation rate between the elevated air temperature treatment and control. Wang et al. (1996) exposed Scots pine to elevated air temperature and reported that if intercellular $\mathrm{CO}_{2}$ concentration was constant, net assimilation was not significantly different between the elevated temperature treatment and control trees. The ability of black spruce to acclimate to temperature was demonstrated by Way and Sage (2008) who grew black spruce in different temperature greenhouses then exposed them to a variety of temperature treatments. Way and Sage showed that black spruce grown at higher temperatures had greater photosynthetic rates at higher temperatures. Likewise, black spruce grown at lower temperatures had higher photosynthetic rates at lower temperatures. Overall these studies found that it is possible for trees grown at similar temperatures to maintain analogous rates of gas exchange comparable to control even if air temperature increases.

Acclimation of autotrophic respiration has also been reported in a variety of other studies, both in situ as well as in a laboratory, for a variety of species (Lavigne 1996, Teskey and Will 1999, Atkin et al. 2000, Loveys et al. 2003, Lee et al. 2005). Our results from this ecosystem-level warming experiment corroborate earlier results for black spruce seedlings grown at different temperatures (Tjoelker et al. 1999). We hypothesized that acclimation would occur, however, we anticipated a transient warming response. We failed to detect any consistent differences in foliage or stem respiration rates in the early growing season or early in the experiment. Lee et al. (2005) reported that $\mathrm{R}_{\mathrm{fol}}$ acclimation occurs quickly and Atkin et al. (2000) reported that respiration acclimation for snow gum occurred in $1-3$ days. If their results are representative for other woody species, it is not unreasonable for there to be little difference in photosynthesis and respiration from the start of the experiment, and detecting any transient response is problematic.

We anticipated having a greater increase in autotrophic respiration in the heated-inside treatment early in the experiment that approached the control treatment over ample time (months or years) due to the production of new foliage during the warming manipulation. While we expected the new foliage may have a respiration and photosynthetic rate closer to control, we predicted the older foliage would have a greater respiration rate than control. However, both the older foliage, which developed before the experiment, and the new foliage, developed during the experiment, had similar rates of $A_{\text {net }}, R_{\text {fol }}$ and $R_{\text {stem }}$ across all treatments. Atkin and Tjoelker (2003) highlight two different types of thermal acclimation, which they refer to as type 1 and type 2 . Type 1 acclimation is a more rapid acclimation and representative of older foliage in this study, which in the heated greenhouses 
maintained rates near the control treatment. Type 2 acclimation is a change in enzymatic activity and usually pertains to foliage that develops during the manipulation. Further investigation is needed to analyze needle chemistry to understand if enzymatic changes did occur in new foliage that developed during the warming manipulation. We believe that our experiment highlights the possibility of having multiple types of thermal acclimation in a single species and underscores the ability of black spruce to maintain homeostasis in a $5{ }^{\circ} \mathrm{C}$ warmer environment.

Examine the effects of warming on major components of the carbon budget: Net primary production and carbon allocation. Bronson, DR and ST Gower. 2009. The effect of ecosystem warming on above- and belowground net primary production for boreal black spruce. Canadian Journal of Forest Research (submitted).

Annual stem diameter increment ranged between 0.2 and $1.65 \mathrm{~cm}$ in 2005, and 0.05 and $1.25 \mathrm{~cm}$ in 2006 (Figure 2). The average annual stem diameter increment ranged between 0.55 and $0.71 \mathrm{~cm}$ in 2005 and between 0.73 and $0.89 \mathrm{~cm}$ in 2006. In 2005 both treatments on the control plot (CI and CO) had a significantly greater increase in stem diameter than the treatments on the heated plots; however there were no significant differences in 2006.

Figure 10. Average increase in annual diameter at breast height (DBH; $137 \mathrm{~cm})$ for 2005 and 2006. Bars are averaged across the four replicate blocks \pm SE.

The understory NPP averaged across the four treatments ranged between 27 and $46 \mathrm{~g} \mathrm{~m}^{-2}$ in 2004 and between 48 and $101 \mathrm{~g} \mathrm{~m}^{-2}$ in 2006 (Figure 3). No statistical differences occurred between the four treatments in 2004. In 2006, understory NPP was significantly greater for HI than the other three treatments.

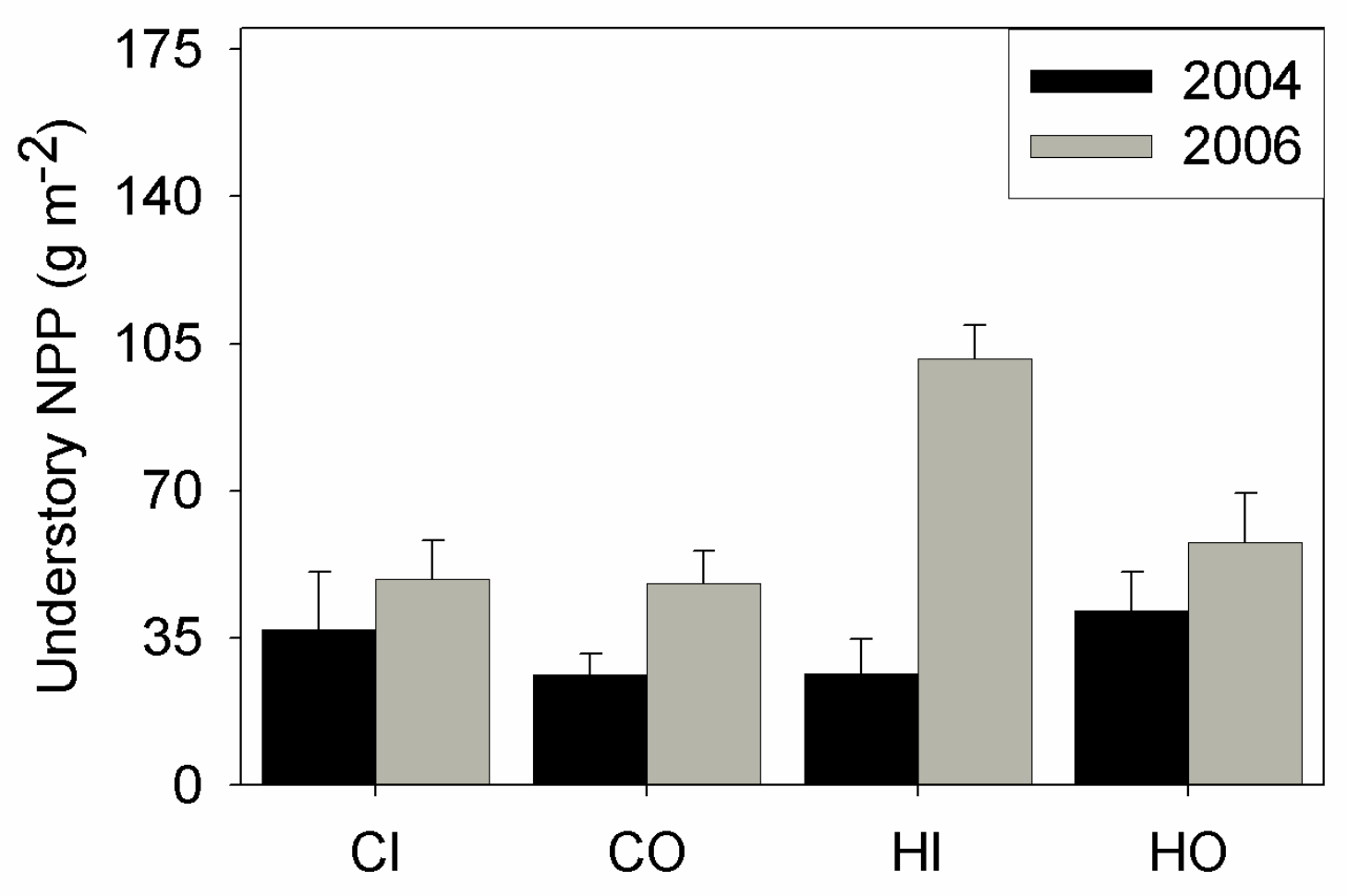


Figure 11. Average understory NPP as $\mathrm{g} \mathrm{m}^{-2}$. Bars are averaged across the four replicate blocks $\pm \mathrm{SE}$.

Twig and needle NPP was not significantly different among treatments in 2005, but was significantly greater for CI and HI than HO and CO in 2006.

Understory NPP was significantly greater for HI than the other treatments in 2006. Stem, branch, and coarse root NPP was not significantly different among treatments in 2005 or 2006.

Unlike needle and twig tissue, there was no difference between treatments for stem or branch tissue for either year. Newly emerged needle and twig tissues are usually a product based upon the previous year's bud and are able to respond faster than older needles, twigs or woody tissues. Fertilization experiments have demonstrated that current-year and one-year old needle and twig growth responds quicker to nitrogen additions, while older needles, twigs, branches and/or stems take a long time to respond (Gower et al. 1991, Gower et al. 1993, Strömgren and Linder 2002, Ozolinčius et al. 2007). It is possible that because black spruce is such a slow growing species, for an increase to occur in stem or branch tissue more than three years of manipulation would be needed.

Fine root NPP was significantly less (33 - 57\%) for the heated than control treatments and the difference between heated and control treatments increased from 2005 to 2006. Even with a significant increase in needle and twig NPP, aboveground NPP was not different between treatments in 2005 or 2006. In 2005 total NPP (aboveground + belowground) was 26\% and 19\% less for HI and HO, respectively than control, but not significant. However, in 2006 total NPP was significantly less for $\mathrm{HI}$ and $\mathrm{HO}$ than control. Results from this experiment suggest that while warming may stimulate needle and twig production, the loss of fine root mass may be significant enough to decrease total NPP in boreal forests. 


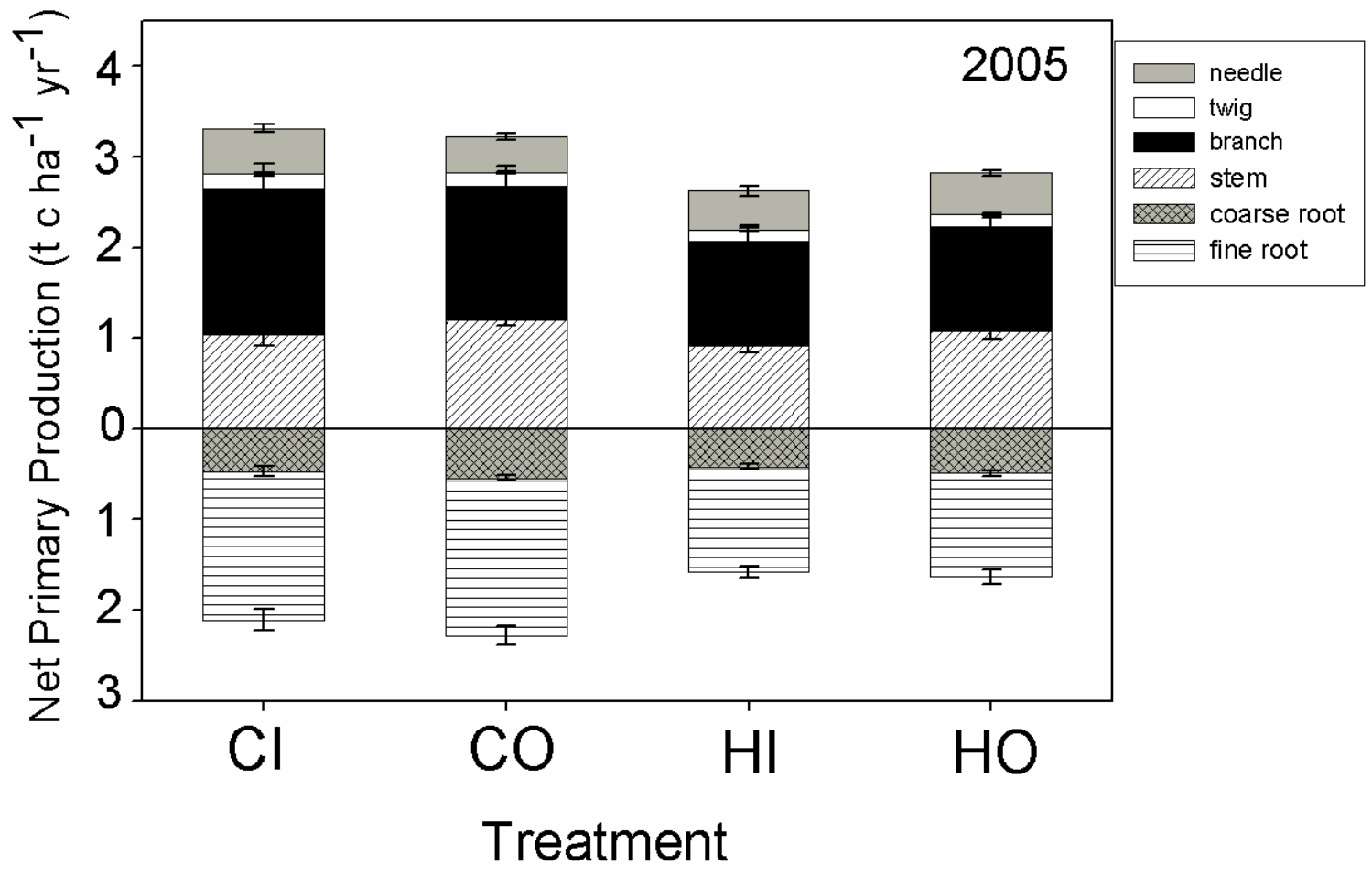




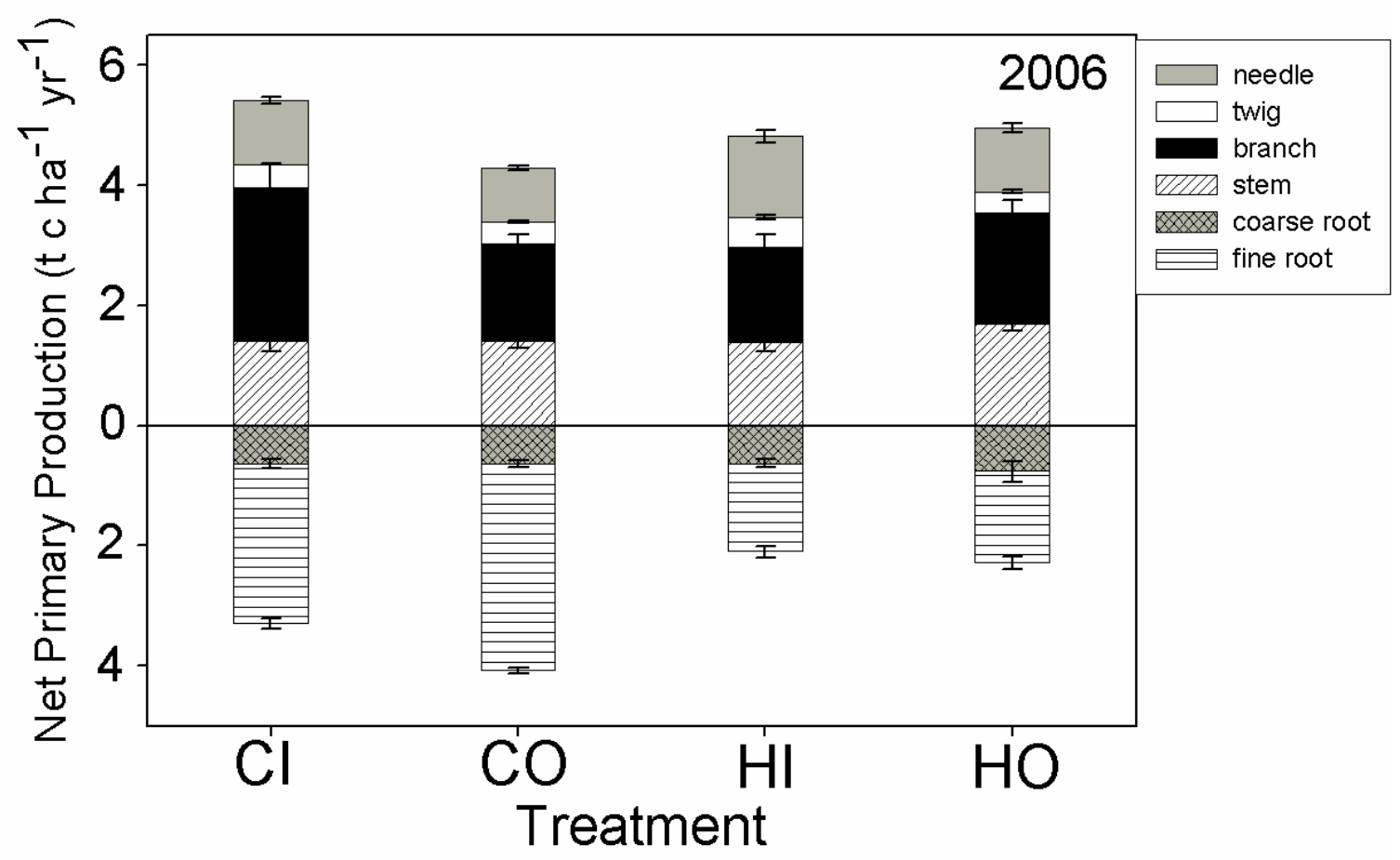

Figure 12 and 13. Estimated black spruce net primary production (NPP) for 2005 and 2006, reported as $\mathrm{t} \mathrm{C} \mathrm{ha-1} \mathrm{yr}^{-1}$. Components of black spruce are listed; needle, twig, branch, stem, coarse root and fine root. Estimates are based on allometric equations which are listed in table 1 . Bars are averages of the four replicate blocks \pm SE. 
Examine the effects of warming on sap flux and respiration. Van Herk, IG, ST Gower DR Bronson, and MS. Tanner. 2009. Effects of climate warming on canopy water dynamics of a boreal black spruce plantation. Canadian Journal of Forest Resources (submitted).

Sap flux (Js), measured using Granier heat dissipation probes, was not significantly different $(p>0.10)$ among treatments in the spring or summer $(p>$ $0.05)$. However, Js was significantly greater $(\mathrm{p}<0.05)$ for HIVPD trees than for trees in all other treatments. (Figure $14 \& 15$ ).

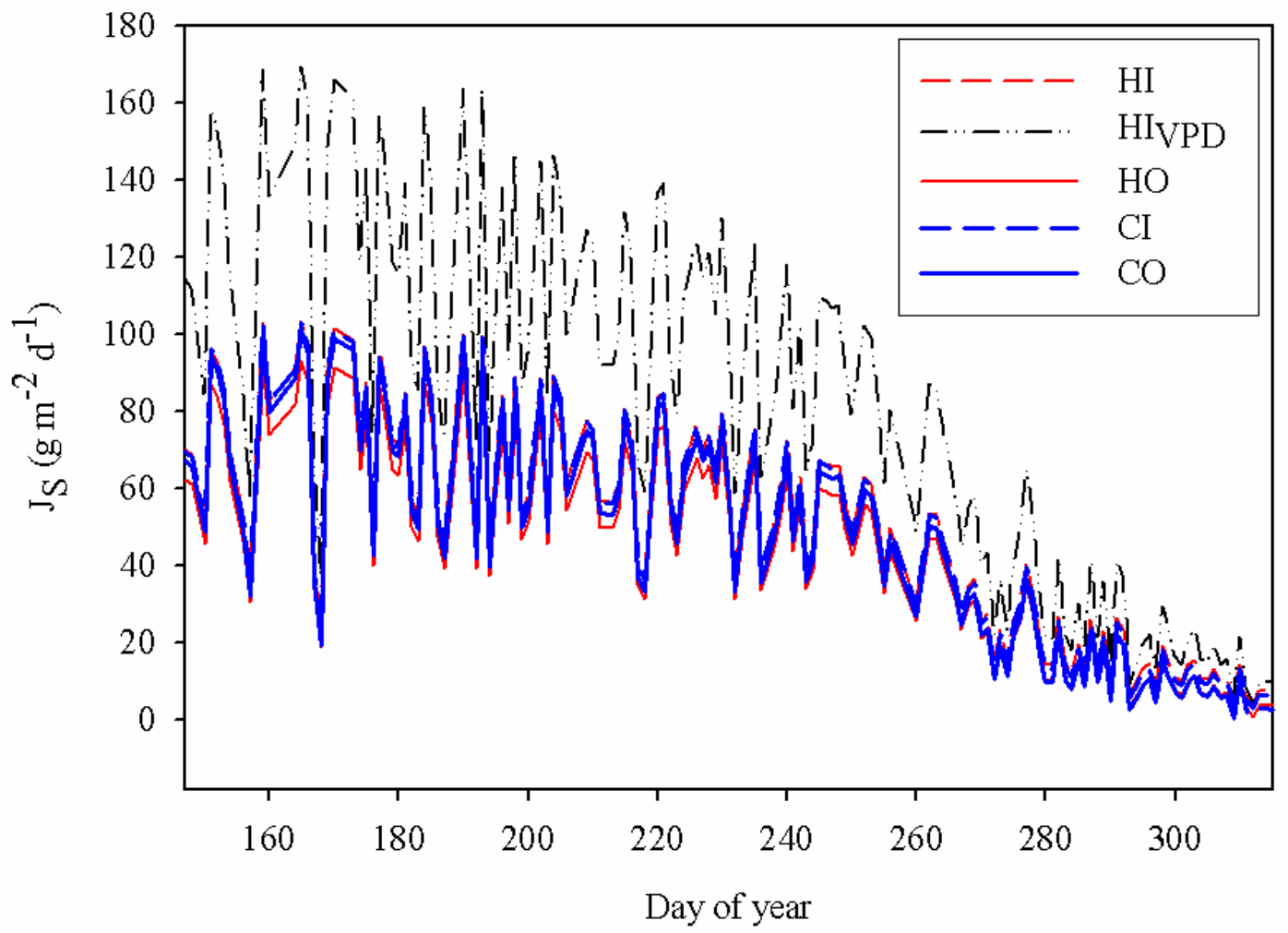

Figure 14. Annual trend of daily JS for the study period (May 27 - November 11, 2006) 

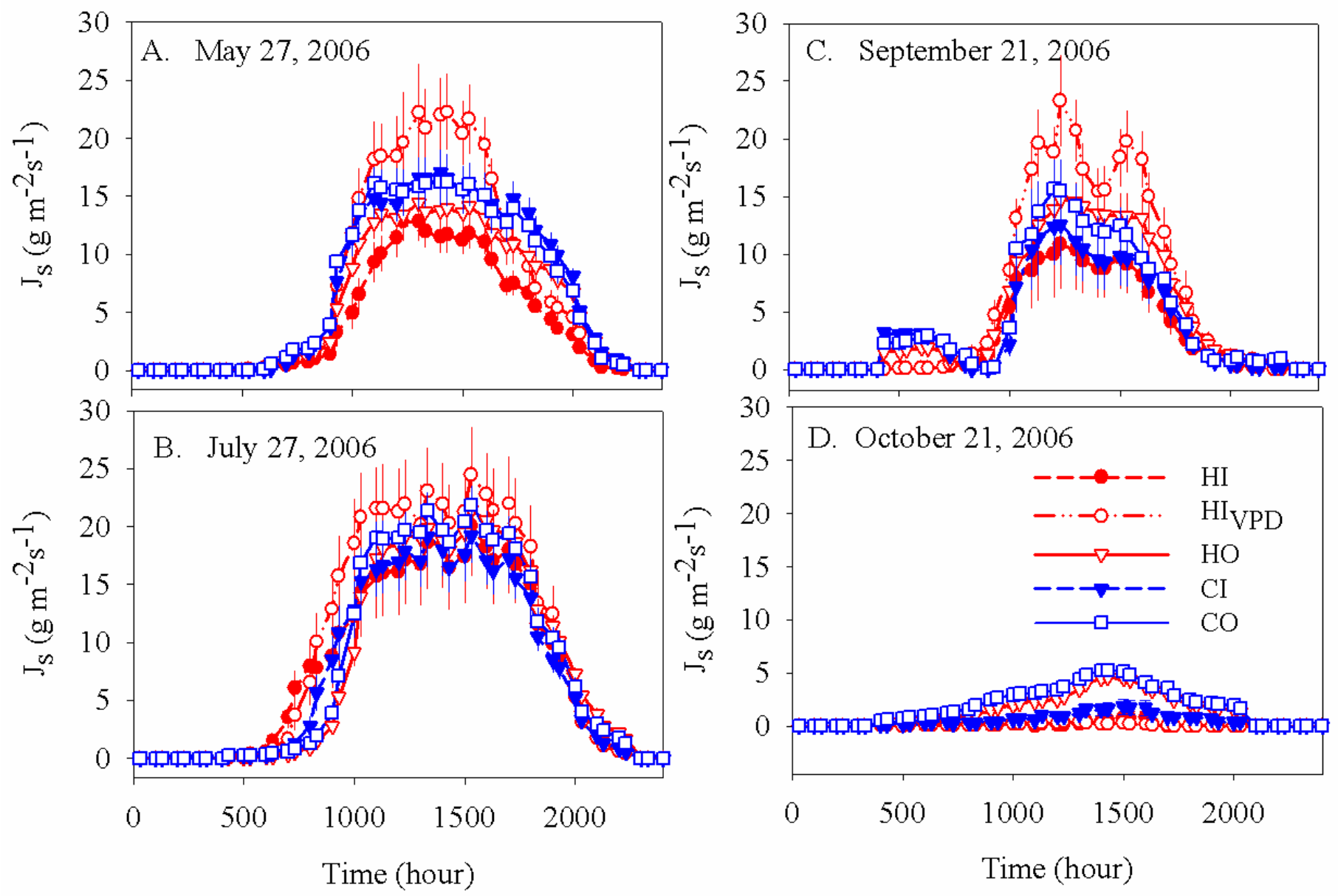

Figure 15. Representation of daily $\mathrm{J}_{\mathrm{S}}$ trends for all treatments. Each graph is of one representative day for spring, summer, fall, and winter. Each point for HI and HIVPD represents the mean of 8 trees. Each point for $\mathrm{CI}, \mathrm{CO}$ and $\mathrm{HO}$ represents the mean of 16 trees. Each bar is 1 standard error.

Js was positively correlated to photosynthetic photon flux density (PPFD) for all trees. PPFD was 27 to 33\% lower inside chambers (treatments HI, CI, HIVPD), than outside the chamber treatments (HO, CO) (Figure 16), therefore, treatment-specific linear models were developed that correlated Js to incident PPFD for each treatment and the models were used to estimate sap flux ( $\left.\mathrm{J}_{s}\right)$ and transpiration $\left(\mathrm{E}_{\mathrm{C}}\right)$. 


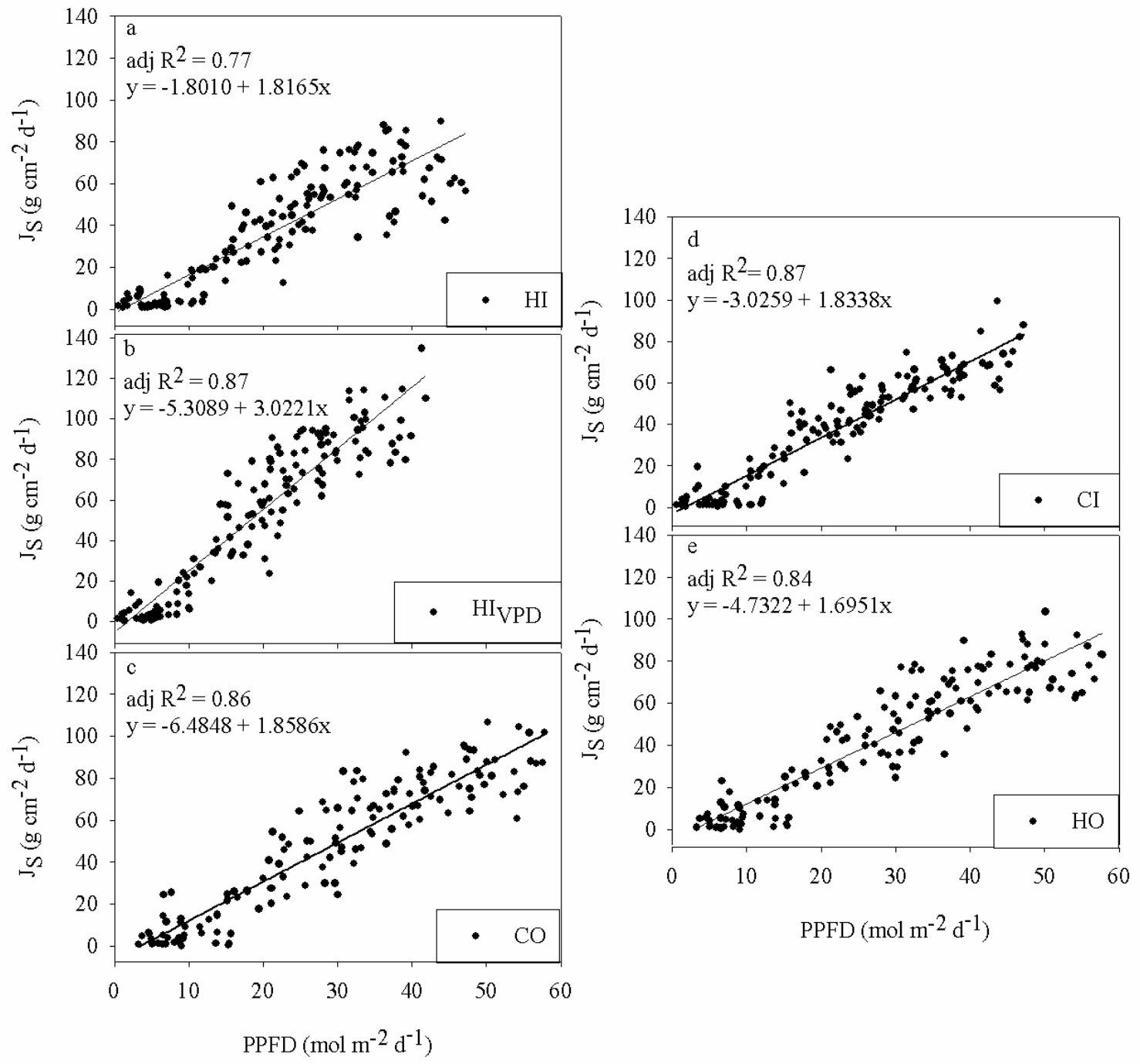

Figure 16. Relationship between mean daily sap flux and daily summed PPFD. $\mathrm{HO}=$ heated outside, $\mathrm{CO}$ values were subtracted from other treatment values to get differentials. $\mathrm{CO}=$ control outside, $\mathrm{HI}=$ inside heated chamber,

$\mathrm{HIVPD}=$ heated chamber with VPD controls, $\mathrm{HO}=$ heated soil, $\mathrm{CI}=$ control chamber . 
Average daily and cumulative growing season $\mathrm{E}_{\mathrm{C}}$ were significantly greater $(p<0.05)$ for HIVPD than other treatments. (Figure 17). The results from this study suggest canopy transpiration and photosynthesis of boreal black spruce will be unchanged or decrease if warmer temperatures increase VPD, but they will increase if climate change decreases VPD. The results from this study suggest canopy transpiration and photosynthesis of boreal black spruce will be unchanged or decrease if warmer temperatures increase VPD, but they will increase if climate change decreases VPD. Other studies on Scots pine found evidence that increases in air temperature, ranging from $2-6^{\circ} \mathrm{C}$, increased transpiration during the summer months, but transpiration was not measured in the fall and spring (Kellomäki and Wang 1998, Wang et al. 2004). Mellander et al. (2004) reported that sap flux did not differ significantly among Scots pine trees on warmed soil and controlled treatments.

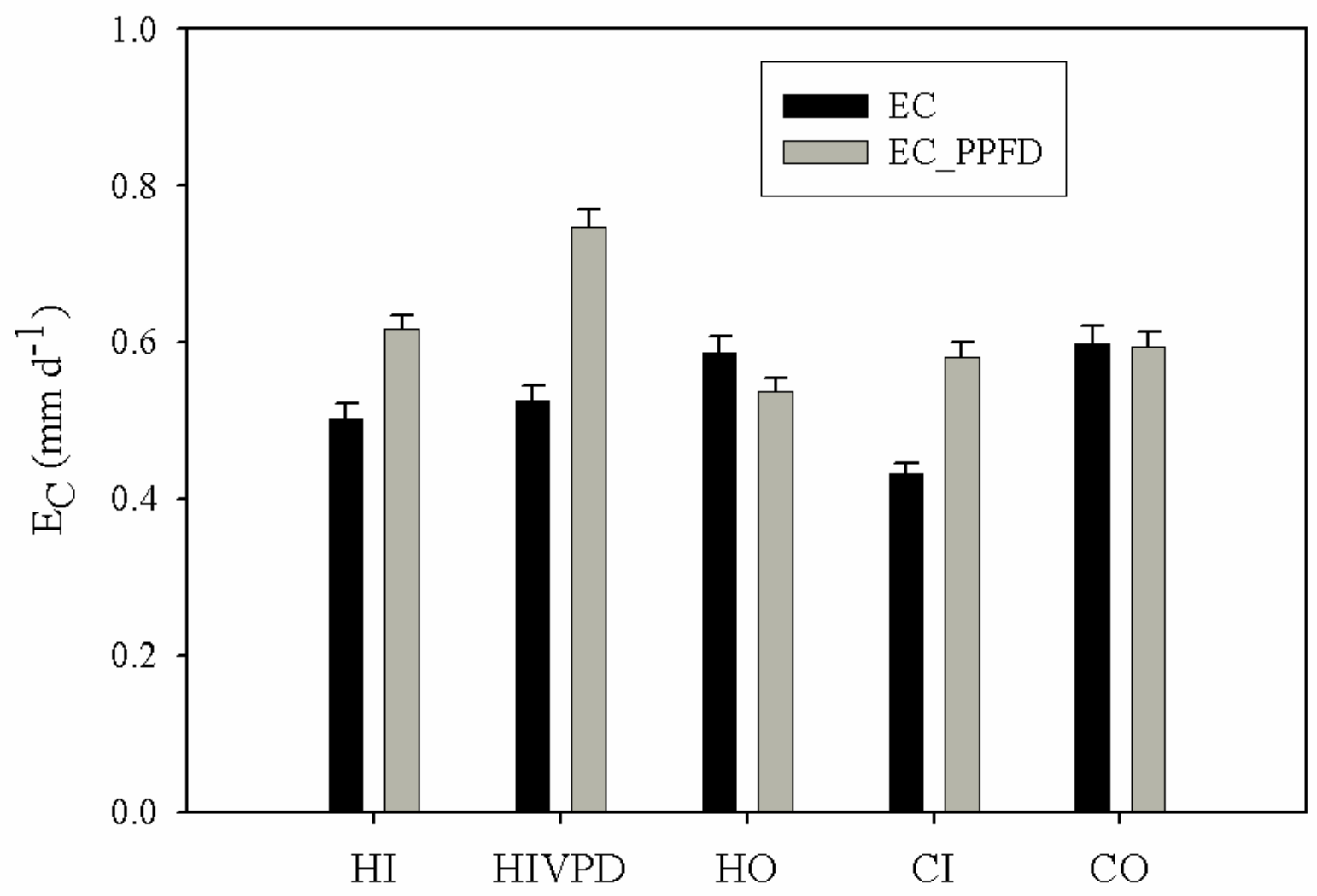

Figure 17.

Canopy transpiration measured values and estimated values based on incident PPFD. $\mathrm{E}_{\mathrm{C}}$ are actual values and $\mathrm{E}_{\mathrm{C}} \_$PPD are estimated using linear regression with incident PPFD. 
